\title{
Bovine GDF10 gene polymorphism analysis and its association with body measurement traits in Chinese indigenous cattle
}

\author{
C. Adoligbe $\cdot$ Linsen Zan · S. Farougou • \\ Hongbao Wang $\cdot$ J. A. Ujjan
}

Received: 29 April 2011 / Accepted: 11 July 2011/Published online: 31 July 2011

(C) The Author(s) 2011. This article is published with open access at Springerlink.com

\begin{abstract}
The objective of this research was to detect bovine GDF10 gene polymorphism and analyze its association with body measurement traits (BMT) of animals sampled from 6 different Chinese indigenous cattle populations. The populations included Xuelong (Xl), Luxi (Lx), Qinchuan (Qc), Jiaxian red (Jx), Xianang (Xn) and Nanyang (Ny). Blood samples were taken from a total of 417 female animals stratified into age categories of 12-36 months. Polymerase chain reaction-single strand conformation polymorphism (PCR-SSCP) was employed to find out GDF10 single polymorphism nucleotide (SNPs) and explore their possible association with BMT. Sequence analysis of GDF10 gene revealed 3 SNPs in total: 1 in exon1 (G142A) and 2 in exon3 (A11471G, and T12495C). G142A and T12495C SNPs are both synonymous mutation. They showed 2 genotypes namely respectively (GG, GA) and (PP and PB). A11471G SNP is a missense mutation leading to the change of Alanine to Threonine amino acid. It showed three genotypes namely $\mathrm{AA}, \mathrm{BB}$ and $\mathrm{AB}$. Analysis of association of polymorphism with body measurement traits at the three locus showed that there were significant effects on BMT in Qc, Jx and Ny cattle population. These results suggest that the GDF10 gene might have potential effects on body measurement traits in the above mentioned cattle populations and could be used for marker-assisted selection.
\end{abstract}

C. Adoligbe $(\bowtie) \cdot$ L. Zan · S. Farougou $\cdot$ H. Wang · J. A. Ujjan College of Animal Science and Technology, Northwest A\&F University, No. 22 Xinong Road, Yangling, Shaanxi 712100, People's Republic of China

e-mail: adolcam83@yahoo.fr

L. Zan $\cdot$ H. Wang

National Beef Cattle Improvement Centre of Northwest A\&F

University, Yangling, Shaanxi, People's Republic of China
Keywords Chinese indigenous cattle - GDF10 - Body measurement traits $\cdot$ SNPS

\section{Introduction}

The principal use of beef cattle is for meat production. In China, industries of meat production have developed rapidly and recently showed an increasingly positive trend. Chinese yellow cattle are known to be good beef cattle because of peculiar qualities, such as strong trunk, crude feed tolerance, high stress resistance, good adaptability, fine beef flavor and so on. However, some drawbacks still stand, such as underdeveloped hind hip and slow growth. It's then necessary to select important functional genes of beef cattle through marker-assisted selection in order to solve the problems of low efficiency in Chinese beef cattle breeding, increase economic benefits and promote the development of domestic cattle industry towards high quality and efficiency.

Bone morphogenetic proteins (BMPs) are members of the transforming growth factor-beta (TGF- $\beta$ ) superfamily [1], which can influence a variety of differentiation processes, including adipogenesis, myogenesis, chondrogenesis, hematopolesis and epithelial cell differentiation [2]. In this superfamily, BMPs were originally identified on the basis of their ability to induce ectopic bone formation when implanted within soft tissue in vivo [3].

Growth differentiation factor 10 (GDF10) is the regulator of cell growth and differentiation in both embryonic and adult tissues. It is one of the most important members of BMPs. [4]. Previous studies in murine allowed GDF10 mRNA detection in both neonatal and adult bone samples with higher levels being detected in calvaria than in long bone $[5,6]$. These results suggest that GDF10 gene may 
play multiple roles in regulating cell differentiation events and skeletal morphogenesis. In order to determine the biological function of GDF10, [7] carried out a detailed analysis of the expression pattern of GDF10. They found that during embryogenesis GDF10 is expressed prominently in developing skeletal structures both in the craniofacial region and in the vertebral column. Additionally, [8] suggested that GDF10 may have novel uncharacterized roles in transducing teratogenic signal in the limb. Furthermore they localized GDF10 in situ hybridization (ISH) to area of programmed cell death in the limb.

BMT are economically important in cattle breeding and their variations have been claimed to be associated with different factors among which genetic factors are predominant. Based on the role of GDF10 in bone morphogenetic as determined in mice and human, GDF10 could be an attractive candidate gene for BMT in bovine genetic improvement. Therefore, the objective of this study is to detect SNP of GDF10 gene in different Chinese indigenous cattle population and explore their possible association with BMT.

\section{Materials and methods}

\section{Experimental animals}

A total of 417 female animals stratified into age categories of 12 months to 36 months which comprises:

- Xl cattle ( $n=50$, Dalian) blood samples collected from Dalian province;

- Lx cattle ( $n=62$, Shandong) blood samples collected from Luxi cattle breeding farm, Heze City Shandong Province;

- Qc cattle ( $n=148$, Shaanxi) blood samples collected from Shaanxi province

Yuanzhong farm and five animal husbandry and technology companies;

- Jx cattle ( $n=71$, Henan) blood samples collected from Pingdingshan city, Henan province;

- Xn cattle ( $n=38$, Henan) blood samples collected from Zhumadian Biyang County, Henan Province;

- Ny cattle ( $n=48$, Henan Province) blood samples collected from cattle conservation farm, Nanyang, Henan Province were randomly selected from breeding population and used to analyze the GDF10 allelic frequencies.

\section{DNA isolation}

Animals blood samples were obtained from the 417 animals and treated with $2 \%$ heparin then stored at $-80^{\circ} \mathrm{C}$.
DNA samples were extracted from blood samples according to standard procedures [9].

Body measurements traits

The traits measured, as described previously [10], included $\mathrm{BL}, \mathrm{BH}, \mathrm{HH}, \mathrm{RL}, \mathrm{HW}, \mathrm{CD}$ and CC. In order to minimize systematic error, the same person was assigned to measure one of the seven traits in all animals.

\section{Primers design}

Based upon the bovine GDF10 gene (GenBank accession No, NC_007329.3), 10 pairs of PCR primers have been designed by Primer Premier 5.0 software to amplify a DNA sequence from GDF10 gene exon1, 2 and 3.

Polymerase chain reaction condition

Polymerase chain reaction (PCR) amplifications were performed in $20 \mu \mathrm{l}$ reaction mixture containing $50 \mathrm{ng}$ DNA template, $10 \mathrm{pM}$ of each primer, $0.20 \mathrm{mM}$ dNTP, $2.5 \mathrm{mM}$ $\mathrm{MgCl}_{2}$ and $0.5 \mathrm{U}$ Taq DNA polymerase (TaKaRa, Dalian, China).

Single strand conformation polymorphism (SSCP) and sequencing

PCR products were analyzed by single-strand conformation polymorphisms (SSCP). Aliquots of $4 \mu \mathrm{l}$ of above PCR products were mixed with $8 \mu$ l of the denaturing solution (95\% formamide, $25 \mathrm{mM}$ EDTA, $0.025 \%$ xylene-cyanole and $0.025 \%$ bromophenol blue), incubated at $98^{\circ} \mathrm{C}$ for $10 \mathrm{~min}$ and then chilled in ice. Denatured DNA was loaded in $8 \%$ to $16 \%$ PAGE gel according to the size of the pair of primer used. The gel was run at constant voltage of $121 \mathrm{~V}$ for a period of time depending on the concentration of the gel. The gel was stained with $0.1 \%$ silver nitrate and visualized with $2 \% \mathrm{NaOH}$ solution (containing $0.1 \%$ formaldehyde) according to [11]. To confirm the results based on PCR-SSCP technique, the PCR products from the mix DNA template were sequenced in both directions. DNAMAN (version 6.0) software was used to analyze the sequences.

Statistical analyses

Genotypic frequencies, allelic frequencies, Hardy-Weinberg equilibriums, gene homozygosity (Ho), gene heterozygosity (He), effective allele numbers (Ne) and polymorphism information content (PIC) were statistically analyzed according to the previous approaches of [12, 13]. The association between SNP marker genotypes of $\mathrm{GDF}_{10}$ 
gene and records of body measurement traits $(\mathrm{BL}, \mathrm{WH}$, $\mathrm{HH}, \mathrm{RL}, \mathrm{HW}, \mathrm{CD}, \mathrm{CC})$ were analyzed by the software SPSS (version 17.0) according to the following statistical linear model:

$\mathrm{Yijk}=\mu+\mathrm{G}_{\mathrm{j}}+\mathrm{A}_{\mathrm{i}}+\mathrm{E}_{\mathrm{ijk}}$

where Yijk is the observation for the body measurement traits, $\mu$ is the overall mean for each trait, $G_{j}$ is the genotype effect, $A_{i}$ is the fixed effect of age and Eijk is the random error.

\section{Results}

PCR-SSCP analysis of the $\mathrm{GDF}_{10}$ gene

10 pairs of PCR primers have been designed to amplify a DNA sequence from GDF10 gene exon1, 2 and 3. Sequence analysis of GDF10 gene revealed 3 SNPs in total, 1 in exon1 (G142A) and 2 in exon3 (A11471G and T12495C). A11471G SNP showed 3 genotypes namely AA, AB and BB (Fig. 2a), whereas both G142A SNP and T12495C SNP showed two genotypes namely GG and GA (Fig. 1a) and PB and PP (Fig. 3a) respectively.

Genetic analysis of bovine $\mathrm{GDF}_{10}$ gene exon 1 and $\chi^{2}$ test

GDF10 exon1 analysis showed that there was a $\breve{G}>A$ synonymous mutation at 142-bp position (Fig. 1b). Genetic diversity of the locus was calculated (Tables 1, 2); mutant allele A was present in five populations out of 6 , and it was less frequent than the wild allele $G$ in the population involved. GG genotype frequency ranged from 0.5968 (Lx) to $1.0000(\mathrm{Ny})$. In all populations except $\mathrm{Ny}$, GA genotype existed and its frequency ranged from $0.1200(\mathrm{Xl})$ to 0.4032 (Lx) (Table 1). The result in Table 2 shows that $\mathrm{Jx}$ and Lx population's heterozygosity, polymorphism information content and effective number of allele's values were higher than that of the other populations. This meant that $\mathrm{JX}$ and Lx polymorphism and genetic variation were the highest; according to the classification of PIC (low polymorphism if PIC value $<0.25$, medium polymorphism if $0.25<\mathrm{PIC}$ value $<0.5$, and high polymorphism if PIC value $>0.5$ ), Lx and $\mathrm{Jx}$ showed medium polymorphism levels whereas Xl, Qc and Xn showed low polymorphism levels. The $\chi^{2}$ test showed that genotypic distributions in all the populations involved agreed with Hardy-Weinberg equilibrium $(P>0.05)$.

Association of polymorphism with body measurement traits at GDF10 exon 1 (142 bp) locus

Analysis of association of polymorphism with BMT at GDF10 exon 1 (142 bp) locus showed that there were significant effects on $\mathrm{HW}, \mathrm{CD},(P<0.01)$ and $\mathrm{CC}$ $(P<0.05)$ in the $\mathrm{Jx}$ cattle population (Table 3$)$. GG genotype had the higher mean value for all the traits involved and might be the favorable genotype.

Genetic analysis of GDF10 gene exon3 and effect of SNP on body measurement traits

Analysis of GDF10 gene exon3 showed that there were 2 mutations namely A11471B and P12495B. Genetic diversity of the loci was calculated.
Fig. 1 a Electrophoresis patterns of PCR-SSCP exon 1 of the bovine $\mathrm{GDF}_{10}$. b Sequencing map of G142A mutation in GDF10 gene exon1
A

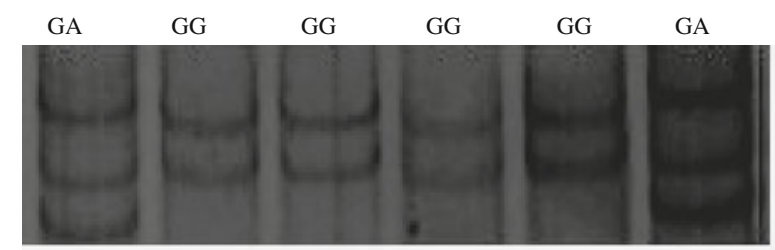

B
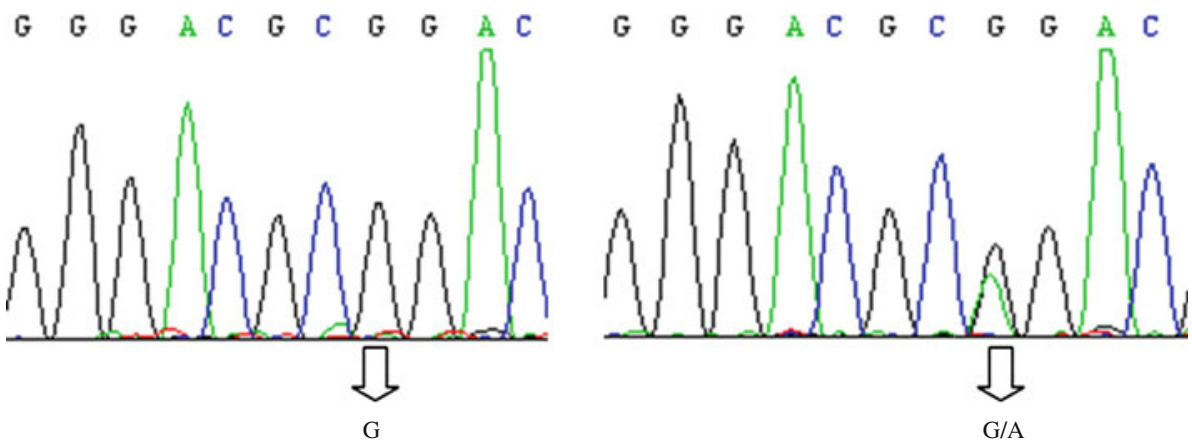
Table 1 Genotype and allele frequencies at 142 bp locus of GDF10 gene exon1

\begin{tabular}{|c|c|c|c|c|c|c|}
\hline \multirow[t]{2}{*}{ Population } & \multicolumn{2}{|c|}{ Genotypic frequencies } & \multirow[t]{2}{*}{ Total } & \multicolumn{2}{|c|}{ Allelic frequencies } & \multirow[t]{2}{*}{$\chi^{2}\left(\mathrm{HW}^{*}\right)$} \\
\hline & GG & GA & & G & A & \\
\hline $\mathrm{Xl}$ & $0.8800(44)$ & $0.1200(06)$ & 50 & 0.9400 & 0.0600 & 0.5747 \\
\hline $\mathrm{Lx}$ & $0.5968(37)$ & $0.4032(25)$ & 62 & 0.7984 & 0.2016 & 2.7554 \\
\hline Qc & 0.7905 (117) & $0.2095(31)$ & 148 & 0.8953 & 0.1047 & 1.0598 \\
\hline Jx & $0.6056(43)$ & $0.3944(28)$ & 71 & 0.8028 & 0.1972 & 3.0844 \\
\hline $\mathrm{Xn}$ & $0.7105(27)$ & $0.2895(11)$ & 38 & 0.8553 & 0.1447 & 0.2400 \\
\hline $\mathrm{Ny}$ & $1.0000(48)$ & $0.0000(00)$ & 48 & 1.0000 & 0.0000 & 0 \\
\hline
\end{tabular}

Table 2 Population genetic indexes at the $\mathrm{GDF}_{10}$ exon 1 (142 bp) region

\begin{tabular}{lllll}
\hline Population & $\begin{array}{l}\text { Gene } \\
\text { homozygosity } \\
(\mathrm{Ho})\end{array}$ & $\begin{array}{l}\text { Gene } \\
\text { heterozygosity } \\
(\mathrm{He})\end{array}$ & $\begin{array}{l}\text { Effective allele } \\
\text { numbers } \\
(\mathrm{Ne})\end{array}$ & $\begin{array}{l}\text { Polymorphic } \\
\text { information content } \\
(\mathrm{PIC})\end{array}$ \\
\hline $\mathrm{Xl}$ & 0.8872 & 0.1128 & 1.1271 & 0.1064 \\
$\mathrm{Lx}$ & 0.6781 & 0.3219 & 1.4748 & 0.2701 \\
$\mathrm{Qc}$ & 0.8125 & 0.1875 & 1.2308 & 0.1699 \\
$\mathrm{Jx}$ & 0.6834 & 0.3166 & 1.4633 & 0.2665 \\
$\mathrm{Xn}$ & 0.7524 & 0.2476 & 1.3290 & 0.2169 \\
$\mathrm{Ny}$ & 1.0000 & 0.0000 & 1.0000 & 0.0000 \\
\hline
\end{tabular}

Table 3 Least square means and standard errors of the body measurement traits obtained for the genotypes of the GDF10 gene polymorphism in Jx cattle population at locus G142A

\begin{tabular}{|c|c|c|c|c|c|c|c|}
\hline \multirow[t]{2}{*}{ Genotype } & \multicolumn{7}{|c|}{ Traits $(\mathrm{cm}$, Means $\pm \mathrm{SE})$} \\
\hline & BL & $\mathrm{BH}$ & $\mathrm{HH}$ & RL & HW & $\mathrm{CD}$ & $\mathrm{CC}$ \\
\hline GG & $137.605 \pm 3.568$ & $125.843 \pm 2.324$ & $126.433 \pm 2.699$ & $43.910 \pm 1.653$ & $41.345 \pm 1.537^{\mathrm{A}}$ & $64.900 \pm 2.134^{\mathrm{A}}$ & $175.119 \pm 2.948^{\mathrm{a}}$ \\
\hline GA & $135.186 \pm 3.463$ & $124.090 \pm 2.256$ & $123.938 \pm 2.619$ & $42.271 \pm 1.604$ & $38.488 \pm 1.492^{\mathrm{B}}$ & $60.443 \pm 2.071^{\mathrm{B}}$ & $171.071 \pm 2.861^{\mathrm{b}}$ \\
\hline
\end{tabular}

\section{Exon3 (11471 bp)}

Genetic analysis

Analysis of GDF10 gene exon3 showed that there was $\mathrm{A}>\mathrm{B}$ missense mutation leading to the change of Alanine to Threonine amino acid at $11471 \mathrm{bp}$ position (Fig. 2b-d). Genetic diversity of the locus was calculated (Tables 4, 5). In the six populations involved, $\mathrm{AB}$ genotype frequency of $\mathrm{Xl}$ and Lx were the highest, $\mathrm{Ny}$ population had the lowest value; AA genotype frequency of $\mathrm{Lx}$ and $\mathrm{Ny}$ were the highest, while the lowest value was that of Xl. In all populations, except in Lx, the BB genotype existed (Table 4). Concerning the others, BB genotype frequency of $\mathrm{Xn}$ was the lowest; Qc population had the highest value.

Table 5 showed that among the six populations, gene homozygosity at this locus was classified in descending order: $\mathrm{Lx}>\mathrm{Ny}>\mathrm{Xl}>\mathrm{Xn}>\mathrm{Jx}>$ Qc.
The polymorphic information content values are in the following order: $\mathrm{Qc}>\mathrm{Jx}>\mathrm{Xn}>\mathrm{Xl}>\mathrm{Ny}>\mathrm{Lx}$. All population showed medium polymorphism. The $\chi^{2}$ test showed that, except Xl population, genotypic distributions in all the populations involved agreed with Hardy-Weinberg equilibrium $(P>0.05)$.

Association of polymorphism with body measurement traits at GDF10 exon3 (11471 bp) locus

Significant difference has been found between genotypes in Qc, Jx and Ny population.

In Qc population there was significant difference between $\mathrm{BB}$ and $\mathrm{AA}$ genotypes and also between $\mathrm{BB}$ and $\mathrm{AB}$ genotypes with $\mathrm{BL}, \mathrm{RL}, \mathrm{HW}$, and $\mathrm{CC}$. On the other hand $\mathrm{BH}$ was significantly different between $\mathrm{AB}$ and $\mathrm{AA}$ genotypes and also $\mathrm{AB}$ and $\mathrm{BB}$ genotype. However in $\mathrm{JX}$ population significant difference appeared between $\mathrm{BB}$ and $\mathrm{AB}$ genotypes with $\mathrm{BL}, \mathrm{CD}$ and $\mathrm{CC}$. In the same way there 
A

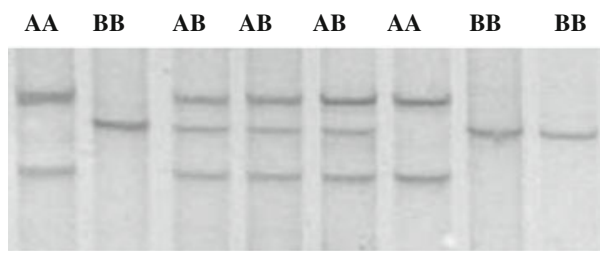

C

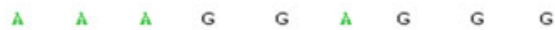

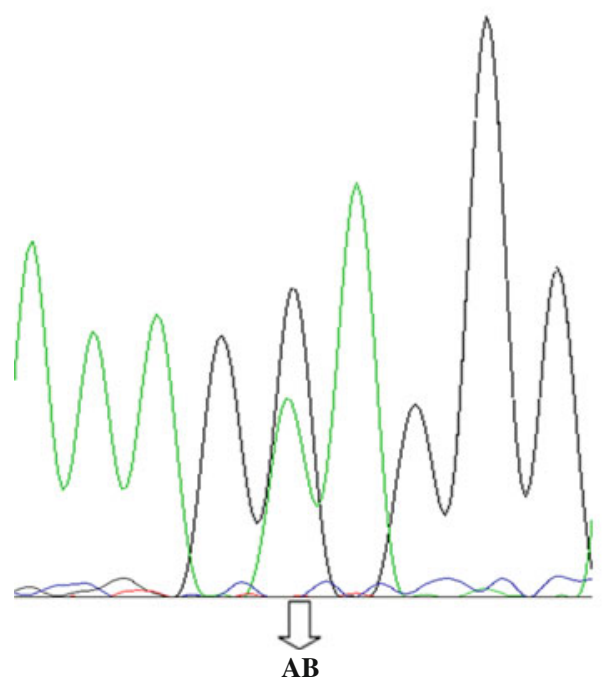

B
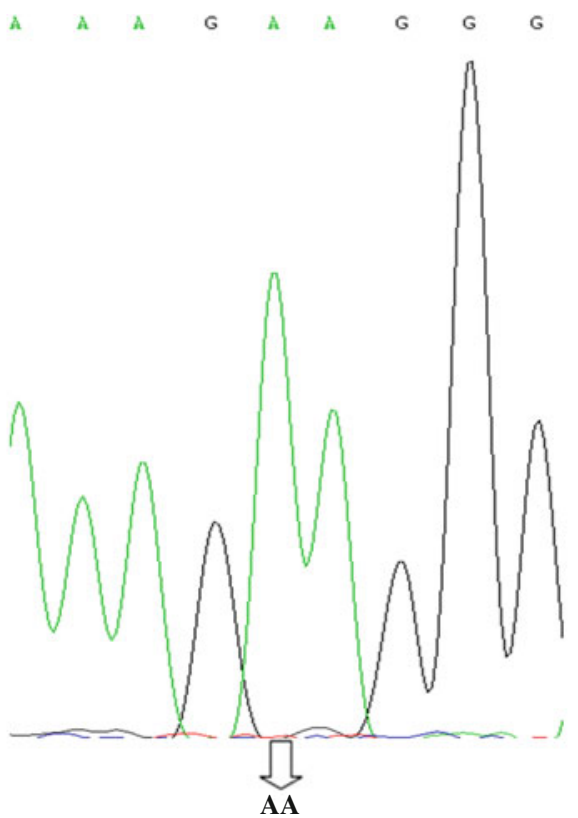

D

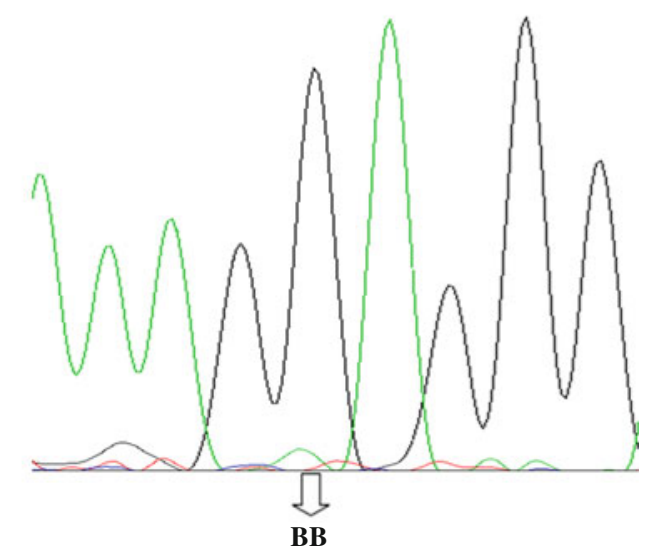

Fig. 2 a SSCP electrophoresis pattern of GDF10 gene exon3 (11471 bp). b-d The sequencing map of the novel SNP of bovine GDF f $_{10}$ exon3 (11471 bp locus)

Table 4 Genotype and Allele frequencies at 11471 bp locus of GDF10 gene exon3

\begin{tabular}{|c|c|c|c|c|c|c|c|}
\hline \multirow[t]{2}{*}{ Population } & \multicolumn{3}{|c|}{ Genotypic frequencies } & \multirow[t]{2}{*}{ Total } & \multicolumn{2}{|c|}{ Allelic frequencies } & \multirow[t]{2}{*}{$\overline{\chi^{2}\left(\mathrm{HW}^{*}\right)}$} \\
\hline & AA & $\mathrm{AB}$ & BB & & A & $\mathrm{B}$ & \\
\hline $\mathrm{X} 1$ & $0.1800(9)$ & $0.5000(25)$ & $0.3200(16)$ & 50 & 0.4300 & 0.5700 & 0.0200 \\
\hline $\mathrm{Lx}$ & $0.5161(32)$ & $0.4839(30)$ & $0.0000(0)$ & 62 & 0.7581 & 0.2419 & 4.9810 \\
\hline Qc & $0.3446(51)$ & $0.3311(49)$ & $0.3243(48)$ & 148 & 0.5101 & 0.4899 & 16.8647 \\
\hline $\mathrm{JX}_{\mathrm{X}}$ & $0.3239(23)$ & $0.3803(27)$ & $0.2958(21)$ & 71 & 0.5141 & 0.4859 & 4.0499 \\
\hline $\mathrm{Xn}$ & $0.3684(14)$ & $0.3421(13)$ & $0.2895(11)$ & 38 & 0.5395 & 0.4605 & 3.6872 \\
\hline Ny & $0.5208(25)$ & $0.1667(8)$ & $0.3125(15)$ & 48 & 0.6042 & 0.3958 & 20.3764 \\
\hline
\end{tabular}


Table 5 Population genetic indexes at the $\mathrm{GDF}_{10}$ exon3 (11471 bp) region

\begin{tabular}{lllll}
\hline Population & $\begin{array}{l}\text { Gene } \\
\text { homozygosity } \\
(\mathrm{Ho})\end{array}$ & $\begin{array}{l}\text { Gene } \\
\text { heterozygosity } \\
(\mathrm{He})\end{array}$ & $\begin{array}{l}\text { Effective allele } \\
\text { numbers } \\
(\mathrm{Ne})\end{array}$ & $\begin{array}{l}\text { Polymorphic } \\
\text { information content } \\
(\mathrm{PIC})\end{array}$ \\
\hline $\mathrm{Xl}$ & 0.5098 & 0.4902 & 1.9616 & 0.3701 \\
$\mathrm{Lx}$ & 0.6332 & 0.3668 & 1.5793 & 0.2995 \\
$\mathrm{Qc}$ & 0.5002 & 0.4998 & 1.9992 & 0.3749 \\
$\mathrm{Jx}$ & 0.5004 & 0.4996 & 1.9984 & 0.3748 \\
$\mathrm{Xn}$ & 0.5031 & 0.4969 & 1.9876 & 0.3734 \\
$\mathrm{Ny}$ & 0.5217 & 0.4783 & 1.9168 & 0.3639 \\
\hline
\end{tabular}

Table 6 Least square means and standard errors of the body measurement traits obtained for the genotypes of the GDF10 gene polymorphism in Qc, Jx and Ny cattle population in exon3 locus (11471 bp)

\begin{tabular}{|c|c|c|c|c|c|c|c|c|}
\hline \multirow[t]{2}{*}{$P$} & \multirow[t]{2}{*}{ G } & \multicolumn{7}{|c|}{ Traits $(\mathrm{cm}$, Means \pm SE) } \\
\hline & & BL & $\mathrm{BH}$ & $\mathrm{HH}$ & RL & HW & $C D$ & $\mathrm{CC}$ \\
\hline \multirow[t]{3}{*}{ QC } & $\mathrm{AA}$ & $129.362 \pm 2.137^{\mathrm{a}}$ & $117.586 \pm 1.428^{\mathrm{b}}$ & $122.822 \pm 1.582$ & $42.983 \pm 0.855^{\mathrm{a}}$ & $41.345 \pm 1.038^{\mathrm{a}}$ & $63.724 \pm 1.042$ & $165.983 \pm 2.957^{\mathrm{a}}$ \\
\hline & $\mathrm{AB}$ & $130.019 \pm 2.215^{\mathrm{a}}$ & $119.056 \pm 1.480^{\mathrm{a}}$ & $123.333 \pm 1.640$ & $42.648 \pm 0.886^{\mathrm{a}}$ & $41.519 \pm 1.076^{\mathrm{a}}$ & $63.537 \pm 1.080$ & $165.148 \pm 3.064^{\mathrm{a}}$ \\
\hline & $\mathrm{BB}$ & $122.609 \pm 2.399^{\mathrm{b}}$ & $116.652 \pm 1.603^{\mathrm{b}}$ & $123.435 \pm 1.777$ & $40.087 \pm 0.960^{\mathrm{b}}$ & $38.048 \pm 1.165^{\mathrm{b}}$ & $63.087 \pm 1.170$ & $155.870 \pm 3.320^{\mathrm{b}}$ \\
\hline \multirow[t]{3}{*}{ JX } & $\mathrm{AA}$ & $129.407 \pm 1.786^{\mathrm{AB}}$ & $118.926 \pm 1.356^{\mathrm{a}}$ & $124.852 \pm 1.428^{\mathrm{a}}$ & $42.074 \pm 0.769$ & $41.907 \pm 0.906$ & $64.963 \pm 1.137^{\mathrm{ab}}$ & $167.593 \pm 1.836^{\mathrm{ab}}$ \\
\hline & $\mathrm{AB}$ & $133.091 \pm 1.978^{\mathrm{A}}$ & $118.364 \pm 1.502^{\mathrm{a}}$ & $124.045 \pm 1.582^{\mathrm{a}}$ & $40.378 \pm 0.852$ & $42.682 \pm 1.004$ & $68.182 \pm 1.260^{\mathrm{a}}$ & $168.182 \pm 2.034^{\mathrm{a}}$ \\
\hline & $\mathrm{BB}$ & $124.813 \pm 2.319^{\mathrm{B}}$ & $114.063 \pm 1.761^{\mathrm{b}}$ & $119.750 \pm 1.855^{\mathrm{b}}$ & $40.813 \pm 1.000$ & $41.188 \pm 1.177$ & $63.688 \pm 1.478^{\mathrm{b}}$ & $161.750 \pm 2.385^{\mathrm{b}}$ \\
\hline \multirow[t]{3}{*}{ NY } & AA & $129.379 \pm 1.746^{\mathrm{ab}}$ & $118.483 \pm 1.398^{\mathrm{ab}}$ & $124.828 \pm 1.398^{\mathrm{ab}}$ & $41.690 \pm 0.752$ & $41.879 \pm 0.881$ & $65.034 \pm 1.138$ & $167.517 \pm 1.819$ \\
\hline & $\mathrm{AB}$ & $132.762 \pm 2.051^{\mathrm{a}}$ & $118.286 \pm 1.562^{\mathrm{a}}$ & $123.190 \pm 1.643^{\mathrm{a}}$ & $42.095 \pm 0.884$ & $42.095 \pm 1.035$ & $67.048 \pm 1.337$ & $166.667 \pm 2.138$ \\
\hline & $\mathrm{BB}$ & $125.267 \pm 2.427^{\mathrm{b}}$ & $114.667 \pm 1.848^{\mathrm{b}}$ & $120.600 \pm 1.944^{\mathrm{b}}$ & $42.067 \pm 1.046$ & $42.067 \pm 1.225$ & $65.267 \pm 1.582$ & $163.667 \pm 2.529$ \\
\hline
\end{tabular}

$P$ population, $G$ genotype

${ }^{\mathrm{a}, \mathrm{b}}$ Means with different superscripts were significantly different $(P<0.05)$

A,B Means with different superscripts were significantly different $(P<0.01)$

was significant difference between $\mathrm{BB}$ and $\mathrm{AB}$ genotype and also between $\mathrm{AA}$ and $\mathrm{AB}$ genotypes with $\mathrm{BH}$ and $\mathrm{HH}$.

In $\mathrm{Ny}$ population significant difference was found between $\mathrm{AB}$ and $\mathrm{BB}$ genotypes with $\mathrm{BL}, \mathrm{BH}$ and $\mathrm{HH}$.

In most of the cases $A B$ genotype had the highest mean value and might be the beneficial genotype (Table 6).

\section{Exon3 (12495 bp)}

Genetic analysis

Analysis of GDF10 gene exon3 showed that there was $P>\mathrm{B}$ synonymous mutation at $12495 \mathrm{bp}$ position (Fig. 3b). Among the 6 populations, PB genotype frequency of $\mathrm{Xl}$ was the highest while that of Qc was the lowest (Table 7). Gene homozygosity at this locus classified in descending order is: $\mathrm{Qc}>\mathrm{Ny}>$ Jx $>$ Xn $>$ Lx $>$ Xl. The polymorphic information content values are in the following order: $\mathrm{Xl}>\mathrm{Lx}>\mathrm{Xn}>$ Ny $>$ Jx $>$ Qx. Xl, Lx, Xn, Ny and Jx showed medium polymorphism while Qc showed low polymorphism (Table 8 ). The $\chi^{2}$ test showed that genotypic distributions in all the populations involved agreed with Hardy-Weinberg equilibrium $(P>0.05)$.

Association of polymorphism with body measurement traits at GDF10 exon3 (12495 bp) locus

Analysis of association of polymorphism with BMT at GDF10 exon3 (12495 bp) locus showed that there were significant effects on $\mathrm{BL}, \mathrm{BH}$ and $\mathrm{HH},(P<0.05)$ in Qc cattle population (Table 9). PB had the higher mean value for all the traits involved and might be the favorable genotype.

\section{Discussion}

Identifying the QTL, which is responsible for the manifestation of economically important traits, will facilitate Chinese indigenous cattle breeding programs. Molecular genetic information is integral to bring about genetic improvement of animal species in order to have significant positive developments. Candidate gene approach is a very vital and crucial method to investigate associations of gene 


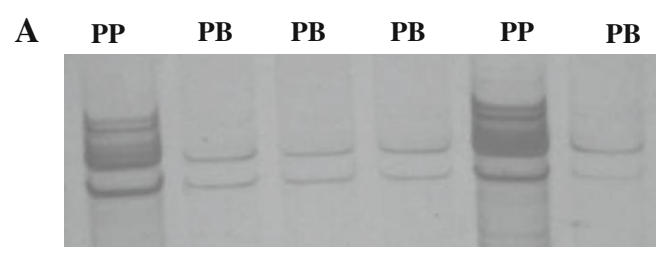

B

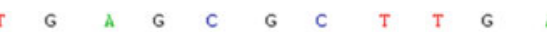

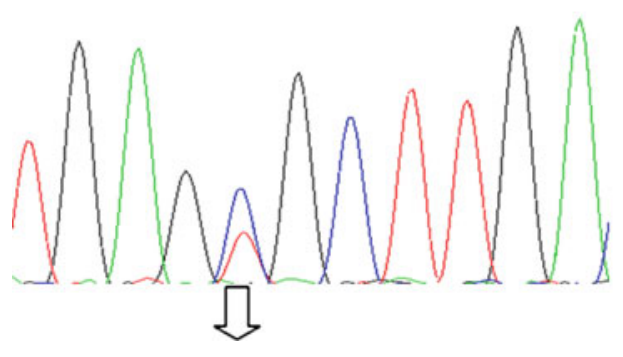

PB

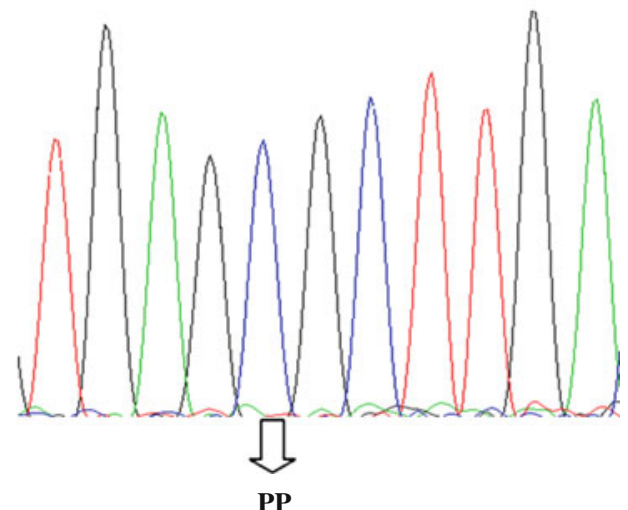

PP

Fig. 3 a SSCP electrophoresis pattern of GDF10 gene exon3 (12495 bp locus). b The sequencing map of the novel SNP of bovine GDF 10 exon3 (12495 bp locus)

Table 7 Genotype and allele frequencies at $12495 \mathrm{bp}$ locus of GDF10 gene exon3

\begin{tabular}{|c|c|c|c|c|c|c|}
\hline \multirow[t]{2}{*}{ Population } & \multicolumn{2}{|c|}{ Genotypic frequencies } & \multirow[t]{2}{*}{ Total } & \multicolumn{2}{|c|}{ Allelic frequencies } & \multirow[t]{2}{*}{$\chi^{2}\left(\mathrm{HW}^{*}\right)$} \\
\hline & PP & PB & & $\mathrm{P}$ & $\mathrm{B}$ & \\
\hline $\mathrm{Xl}$ & $0.3200(16)$ & $0.6800(34)$ & 50 & 0.6600 & 0.3400 & 13.2691 \\
\hline $\mathrm{Lx}$ & $0.3871(24)$ & $0.6129(38)$ & 62 & 0.6935 & 0.3065 & 12.1049 \\
\hline Qc & $0.7973(118)$ & $0.2027(30)$ & 148 & 0.8986 & 0.1014 & 0.9328 \\
\hline $\mathrm{Jx}$ & $0.4930(35)$ & $0.5070(36)$ & 71 & 0.7465 & 0.2535 & 8.1894 \\
\hline $\mathrm{Xn}$ & $0.4211(16)$ & $0.5789(22)$ & 38 & 0.7105 & 0.2895 & 6.3073 \\
\hline $\mathrm{Ny}$ & 0.5625 & $0.4375(21)$ & 48 & 0.7813 & 0.2188 & 2.5374 \\
\hline
\end{tabular}

Table 8 Population genetic indexes at the $\mathrm{GDF}_{10}$ exon3 (12495 bp)

\begin{tabular}{lllll}
\hline Population & $\begin{array}{l}\text { Gene } \\
\text { homozygosity } \\
(\mathrm{Ho})\end{array}$ & $\begin{array}{l}\text { Gene } \\
\text { heterozygosity } \\
(\mathrm{He})\end{array}$ & $\begin{array}{l}\text { Effective allele } \\
\text { numbers } \\
(\mathrm{Ne})\end{array}$ & $\begin{array}{l}\text { Polymorphic } \\
\text { information content } \\
(\mathrm{PIC})\end{array}$ \\
\hline $\mathrm{Xl}$ & 0.5512 & 0.4488 & 1.8142 & 0.3481 \\
$\mathrm{Lx}$ & 0.5749 & 0.4251 & 1.7394 & 0.3347 \\
$\mathrm{Qc}$ & 0.8178 & 0.1822 & 1.2227 & 0.1656 \\
$\mathrm{JX}$ & 0.6215 & 0.3785 & 1.6090 & 0.3069 \\
$\mathrm{Xn}$ & 0.5886 & 0.4114 & 1.6988 & 0.3267 \\
$\mathrm{Ny}$ & 0.6582 & 0.3418 & 1.5193 & 0.2834 \\
\hline
\end{tabular}

polymorphisms with economically important traits in farm animals [14]. Many previous studies have examined growth [15], skeletal muscle [16], physiological [17, 18], reproductive [19-21], meat quality [22] traits using the candidate gene approach in cattle in order to explain their associations.
Transforming growth factor (TGF) super family is a group of multifunctional proteins that are regulators of cell growth and differentiation in both embryonic and adult tissues [5, 23]. Growth differentiation factor 10 (GDF10), also known as BMP-3b and closely related to bone morphogenetic protein 3 (BMP3), is one of the important 
Table 9 Least square means and standard errors of the body measurement traits obtained for the genotypes of the GDF10 gene polymorphism in QC cattle population at exon3 (12495 bp) locus

\begin{tabular}{|c|c|c|c|c|c|c|c|}
\hline \multirow[t]{2}{*}{ Genotype } & \multicolumn{7}{|c|}{ Traits $(\mathrm{cm}$, Means $\pm \mathrm{SE})$} \\
\hline & $\mathrm{BL}$ & WH & $\mathrm{HH}$ & RL & HW & $\mathrm{CD}$ & $\mathrm{CC}$ \\
\hline PP & $123.860 \pm 1.102^{\mathrm{b}}$ & $143.160 \pm 2.107^{\mathrm{b}}$ & $128.270 \pm 0.983^{\mathrm{b}}$ & $40.378 \pm 1.604$ & $41.188 \pm 1.170$ & $65.022 \pm 1.123$ & $167.17 \pm 1.819$ \\
\hline PB & $128.030 \pm 1.285^{\mathrm{a}}$ & $147.236 \pm 2.256^{\mathrm{a}}$ & $135.263 \pm 1.793^{\mathrm{a}}$ & $42.271 \pm 0.432$ & $41.022 \pm 1.118$ & $65.367 \pm 1.582$ & $166.071 \pm 2.861$ \\
\hline
\end{tabular}

a,b Means with different superscripts were significantly different $(P<0.05)$

members of this super family protein. It is able to induce endochondral bone formation [1] and possibly plays multiple roles in regulating cell differentiation events, including those involved in skeletal morphogenesis [5]. GDF10 has been discovered in rat and human femur tissue [23, 24]. Moreover, GDF10 has been localized in situ hybridization (ISH) to area of programmed cell death in the limb [8]. All of the above findings provided evidence that GDF10 may influence BMT.

In this study the possible relationship between GDF10 polymorphism and the seven body measurement traits, BL, $\mathrm{BH}, \mathrm{HH}, \mathrm{RL}, \mathrm{HW}, \mathrm{CD}$ and $\mathrm{CC}$, was evaluated using blood samples from 417 cattle belonging to six different cattle populations. Sequence analysis of GDF10 gene revealed 3 SNPs in total, 1 in exon1 (G142A) and 2 in exon3 (A11471G and T12495C). A11471G SNP showed 3 genotypes (AA, AB and $\mathrm{BB}$ ) whereas both G142A SNP and T12495C showed two genotypes namely (GG, AG) and $(\mathrm{PB}, \mathrm{PP})$ respectively. Association between SNPs and BMT has been analyzed. It seems that G142A SNP is associated with $\mathrm{HW}, \mathrm{CD}$ and $\mathrm{CC}$ only in Jx cattle population. A11471G SNP is associated with BL, BH, RL, HW and $\mathrm{CC}$ in Qc cattle population, with $\mathrm{BL}, \mathrm{BH}, \mathrm{HH}, \mathrm{CD}$ and $\mathrm{CC}$ in $\mathrm{Jx}$ cattle population and with $\mathrm{BL}$ and $\mathrm{HH}$ in $\mathrm{Ny}$ cattle population. T12495C SNP is associated with BL, $\mathrm{WH}$ and $\mathrm{HH}$ only in Qc cattle population. The association of BMT with T12495C SNPs in Qc cattle population and that of G142A SNP in Jx cattle population only may be correlated to other direct or indirect factors specific to the respective cattle population. At 142 bp locus, GG genotype appeared to be the beneficial genotype; at 11471 and 12495 bp respectively AB and $\mathrm{PB}$ appeared to be beneficial genotype. G142A and T12495C SNPs are all synonymous mutations whereas A11471G SNP appears to be a missense mutation inducing the replacement of an Alanine amino-acid by a Threonine amino-acid at the current locus. This change of amino acid may have an impact in terms of function of the protein produced by GDF10 gene. The absence of GA genotype in Ny cattle population at $142 \mathrm{bp}$ locus and of BB genotype at $11471 \mathrm{bp}$ locus in Lx cattle population can be explained in two ways: either GA and $\mathrm{BB}$ genotypes does not exist in the respective population or the size of sample used was small; Our results provide evidence that the GDF10 gene probably has potential effects on body measurement traits in the above mentioned cattle populations.

In the TGF- $\beta$ superfamily, growth differentiation factor 5 and BMP4 were found to be associated with body measurement traits $[15,25,26]$. Beside, BMP4 and GDF9 were found to be associated with litter size in goat [20, 27]. Based on the results obtained from the research it can be inferred that mutation in the coding regions of GDF10 gene has an effect on growth traits in Chinese indigenous cattle. Therefore, I recommend that further research will be necessary to use the SNPs for marker-assisted selection (MAS) in a larger population size. It is also necessary to investigate what is the impact of A12377G SNP on GDF10 protein function.

Acknowledgments We would like to thank all the investigators, research assistants and laboratory technicians who have contributed to this study. We extend special thanks to Professor Zan, Dr Wang, Song Fubiao, Gaoli and Wang Hongcheng for their technical assistance. This work was funded by the National " 863 " Program of China (2006AA10Z1A1, 2008AA101010, 2010AA10Z101), Program for Changjiang Scholars and Innovative Research Team (IRT0940) and the "13115" Scientific and Technological Innovation Program of Shaanxi Province (2007ZDCY-01).

Open Access This article is distributed under the terms of the Creative Commons Attribution Noncommercial License which permits any noncommercial use, distribution, and reproduction in any medium, provided the original author(s) and source are credited.

\section{References}

1. Wozney JM, Rosen V, Celeste AJ, Mitsock LM, Whitters MJ, Kriz RW et al (1988) Tissue growth and repair program, Genetics Institute, Inc., Cambridge, MA 02140. Science 242(4885): $1528-1534$

2. Massegue J (1987) The TGF-beta family of growth and differentiation factor. Cell 49:437-438

3. Urist MR (1965) Bone: formation by autoinduction. Science 150:893-899

4. Hino J, Kangawa K, Matsuo H, Nohno T (2004) Bone morphogenetic protein-3 family members and their biological functions. Front Biosci 9:1520-1529

5. Cunningham NS, Jenkins NA, Gilbert DJ, Copeland NG, Reddi, Lee SJ (1995) Growth/differentiation factor-10: a new member of 
the transforming growth factor-beta super family related to bone morphogenetic protein-3. Growth Factors Res 12(2):99-109

6. Takao M, Hino J, Takeshita N, Konno Y, Nishizawa T, Matsuo H et al (1996) Identification of rat bone morphogenetic protein-3b (BMP-3b), a new member of BMP-3. Biochem Biophys Res Commun 219:656

7. Zhao R, Lawler AM, Lee SJ (1999) Characterization of GDF-10 expression patterns and null mice. Dev Biol 212(1):68-79

8. Eugene G, Barbara FH (2008) Retinoic acid receptor gammainduced misregulation of chondrogenesis in the murine limb bud in vitro. Toxicol Sci 106(1):223-232

9. Sambrook J, Russell DW (2002) Molecular cloning. A laboratory manual, 3rd edn. Sci. Press, Beijing

10. Gilbert RP, Bailey DR, Shannon NH (1993) Linear body measurements of cattle before and after 20 years of selection for postweaning gain when fed two different diets. J Anim Sci 71:1712-1720

11. Zhang CL, Wang Y, Chen H, Lan XY (2007) Enhance the efficiency of single-strand conformation polymorphism analysis by short polyacrylamide gel and modified silver staining. Anal Biochem 365:286-287

12. Nei M, Roychoudhury AK (1974) Sampling variances of heterozygosity and genetic distance. Genetics 76:379-390

13. Nei M, Li WH (1979) Mathematical model for studying genetic variation in terms of restriction endonucleases. Proc Natl Acad Sci USA 76:5269-5273

14. Rothschild MF, Soller M (1997) Candidate gene analysis to detect genes controlling traits of economic importance in domestic livestock. Probe Newsl Agric Genomic 8:13-20

15. Fang X, Xu H, Zhang C, Chen H, Hu X, Gao X, Gu C, Yue W (2009) Polymorphism in BMP4 gene and its association with growth traits in goats. Mol Biol Rep 36(6):1339-1344

16. Schulz RA, Yutzey KE (2004) Calcineurin signaling and NFATactivation in cardiovascular and skeletal muscle development. Dev Biol 266:1-16

17. Emma JG, Stuart ED, Jagadish P, Someshwar Z (2010) Functional gene analysis suggests different acetogen populations in the bovine rumen and tammar walla by forestomach. Appl Environ Microbiol 76(23):7785-7795
18. Li M, Chen Q, Sun G, Shi X, Zhao Q, Zhang C, Zhou J, Qin N (2010) Characterization and expression of bone morphogenetic protein 4 gene in postnatal pigs. Mol Biol Rep 37(5):2369-2377

19. Chu M, Jia L, Zhang Y, Jin M, Chen H, Fang L, Di R, Cao G, Feng T, Tang Q, Ma Y, Li K (2011) Polymorphisms of coding region of BMPR-IB gene and their relationship with litter size in sheep. Mol Biol Rep 38(6):4071-4076

20. Chu MX, Lu L, Feng T, Di R, Cao GL, Wang PQ, Fang L, Ma YH, Li K (2010) Polymorphism of bone morphogenetic protein 4 gene and its relationship with litter size of Jining Grey goats. Mol Biol Rep 37(8):3921-3929

21. Chu MX, Zhao XH, Zhang YJ, Jin M, Wang JY, Di R, Cao GL, Feng T, Fang L, Ma YH, Li K (2010) Polymorphisms of BMPRIB gene and their relationship with litter size in goats. Mol Biol Rep 37(8):4033-4039

22. Shin SC, Chung ER (2007) Association of SNP marker in the leptin gene with carcass and meat quality traits in Korean cattle. Asian-Australas. J Anim Sci 20:1-6

23. Hino J, Matsuo H, Kangawa K (1999) Bone morphogenetic protein-3b (BMP-3b) gene expression is correlated with differentiation in rat calvarial osteoblasts. Biochem Biophys Res Commun 256(2):419-424

24. Hino J, Takao M, Takeshita N, Konno Y, Nishizawa T, Matsuo H et al (1996) cDNA cloning and genomic structure of human bone morphogenetic protein-3B (BMP-3b). Biochem Biophys Res Commun 223(2):304-310

25. Liu YF, Zan LS, Li K, Zhao SP, Ya PX, Qing L et al (2010) A novel polymorphism of GDF5 gene and its association with body measurement traits in Bos taurus and Bos indicus breeds. Mol Biol Rep 37:429-434

26. Zhong X, Zan LS, Wang HB, Liu YF (2010) Polymorphic CA microsatellites in the third exon of the bovine BMP4 gene. Genet Mol Res 9(2):868-874

27. Feng T, Geng CX, Lang XZ, Chu MX, Cao GL, Di R, Fang L, Chen HQ, Liu XL, Li N (2010) Polymorphisms of caprine GDF9 gene and their association with litter size in Jining Grey goats. Mol Biol Rep [Epub ahead of print] 